\title{
Perilaku Sosial Masyarakat Bengkulu terhadap Penggunaan Media Sosial sebagai Diseminasi Informasi, Bimbingan Pribadi-Sosial dan Deradikalisasi
}

\author{
Zubaedi, Prio Utomo*, Ahmad Abas Musofa \\ Islamic Education, Universitas Islam Negeri Fatmawati Sukarno Bengkulu, Indonesia \\ Islamic Guidance and Counseling, Universitas Islam Negeri Fatmawati Sukarno Bengkulu, Indonesia \\ History of Islamic Civilization, Universitas Islam Negeri Fatmawati Sukarno Bengkulu, Indonesia \\ *Corresponding Author \\ Jl. Raden Fatah, Pagar Dewa, Selebar, Kota Bengkulu \\ E-mail: prio.um1990@gmail.com

$\begin{array}{cccl}\text { Received: } & \text { Revised: } & \text { Accepted: } & \text { Published: } \\ \text { 23 September 2021 } & \text { 08 October 2021 } & \text { 12 October 2021 } & \text { 28 November 2021 }\end{array}$

\begin{abstract}
Abstrak
Tujuan Pengabdian kepada Masyarakat (PkM) ini untuk memotret perilaku sosial masyarakat Bengkulu terhadap penggunaan media sosial sebagai diseminasi informasi, bimbingan pribadi-sosial dan deradikasisasi. Kegiatan pengabdian ini dilaksanakan pada tahun 2020 di provinsi Bengkulu. Sampel berjumlah 400 responden. Pengumpulan data menggunakan skema mobile survey, melalui proses deep interview dan kuisioner via mobile. Analisis data menggunakan aplikasi survey (alvara-analytic). Hasil kegiatan pengabdian diperoleh temuan (1) Masyarakat melek digital, potret sikap dan perilaku masyarakat menunjukkan bahwa mereka aktif menggunakan media sosial sebagai sarana berbagi informasi melalui pemanfaatan fitur-fitur yang ada untuk menyebarkan informasi; (2) Penggunaan dan diseminasi media sosial efektif dapat membimbing masyarakat (pribadi-sosial) terhadap pembentukan sikap dan perilaku dalam cegah tangkal paham radikalisme. Kegiatan pengabdian diperoleh kesimpulan indeks potensi radikalisme di Provinsi Bengkulu pada tahun 2020 berada dalam kategori rendah, hal ini menandai bahwa masyarakat mampu dengan baik menggunakan media sosial sebagai deradikalisasi.
\end{abstract}

Kata kunci: media sosial; bimbingan pribadi-sosial; deradikalisasi.

\begin{abstract}
The purpose of this community service is to photograph the social behavior of the Bengkulu people towards the use of social media as information dissemination, personal-social guidance and deradicalization. This service activity was carried out in 2020 in Bengkulu province. The research sample amounted to 400 respondents. Data collection uses a mobile survey scheme, through a deep interview process and questionnaires via mobile. Data analysis using survey application (alvara-analytic). The results of the service activities obtained findings: (1) Digital literacy communities, portraits of people's attitudes and behavior indicate that they are actively using social media as a means of sharing information through the use of existing features to disseminate information; (2) The effective use and dissemination of social media can guide the community (personal-social) towards the formation of attitudes and behavior in preventing radicalism. The service activities concluded that the index of potential for radicalism in Bengkulu Province in 2020 was in the low category, this indicates that the community is able to properly use social media as deradicalization.
\end{abstract}

Keywords: social media; personal-social guidance; deradicalization 
Indonesian Journal of Community Services

Volume 3, No. 2, November 2021

http://jurnal.unissula.ac.id/index.php/ijocs

DOI: http://dx.doi.org/10.30659/ijocs.3.2.193-202

\section{PENDAHULUAN}

Kegiatan Pengabdian kepada Masyarakat (PkM) ini dilatarbelakangi survei nasional oleh Badan Nasional Penanggulangan Terorisme (BNPT) melalui Forum Koordinasi Pencegahan Terorisme (FKPT) pada tahun 2017, melaporkan terdapat lima Provinsi di Indonesi terindikasi pada potensi radikalisme, kelima kota tersebut meliputi (1) Bengkulu sebesar 58,58\%; (2) Gorontalo 58,48\%; (3) Sulawesi Selatan 58,42 \%; (4) Lampung 58,38\%; (5) Kalimantan Utara 58,32\%. Menanggapi laoran tersebut, pada hari Rabu tanggal 18 April 2018 Mabes Polri mengadakan diskusi panel (FGD) di Polda Bengkulu dengan tema melawan radikalisme-terorisme: menjaga keutuhan dan kedaulatan NKRI' yang dihadiri oleh Bhabinkamtibmas, Santri dan tokoh Agama, Masyarakat dan Adat. Hasil FGD menghasilkan kesimpulan pencegahan dan penangkalan radikalisme dan terorisme adalah tanggung jawab bersama-sama baik itu pihak pemerintah, masyarakat dan lembaga agama diharapkan dapat bersinergi serta bersatu padu mencegah masuknya dan berkembangnya gerakan radikalisme di Provinsi Bengkulu.

Apa yang telah dipaparkan di atas merupakan gambaran perkembangan gerakan radikalisme di Indonesia khususnya di Provinsi Bengkulu. Dalam pengertiannya, radikalisme adalah pandangan atau ideologi yang mengarahkan pada tindakan garis keras atau kekerasan sebagai cara dan strategi dalam mencapai tujuan, radikalisme merupakan aliran atau gerakan yang mengharapkan suatu perubahan atau pembaharuan baik itu di bidang sosial dan politik dengan cara kekerasan. Pengertian lain mengatakan radikalisme adalah tindakan perubahan yang memiliki kecenderungan menggunakan kekerasan (Salenda, 2011). Radikalisme cenderung identik dengan tindak kekerasan bahkan sampai pada bunuh diri menuju kebermaknaan hidup yang diyakininya (Golose, 2009).

Gerakan radikalisme muncul dengan tujuan untuk mendoktrin masyarakat, yaitu memberikan pemahaman dan keyakinan pada masyarakat akan perubahan dan pembaharuan tatanan sosial, politik dan agama. Karena itu sasaran utama penyebaran paham dan gerakan radikalisme adalah masyarakat. Hal ini didasari bahwa masyarakat pada umumnya mereka masih rentan terhadap terpaan-terpaan dan kerentanan sosial. Salah satu terpaan dan kerentanan yang marak terjadi adalah paham radikalisme. Maraknya terpaan dan kerentanan paham radikalisme menjadikan masyarakat rawan dan mudah terpapar, bahkan ada yang menjadi simpatisan dan pelaku radikal dan teror. Diduga kuat, faktor yang menjadikan terpaan paham radikalisme berhasil membuat masyarakat terpapar adalah adanya kerentanan sosial. Kerentanan sosial adalah kondisi negatif pada masyarakat itu sendiri yang akhirnya mereka mudah terjerumus dan masuk dalam paham negatif. Jika masyarakat mampu dengan baik mengelola terpaan dan kerentanan dengan baik, maka terpaan dan kerentanan tersebut dapat menjadi daya tangkal (deradikalisasi).

Dilihat dari prosesnya, masuk dan berkembangnya gerakan radikalisme melalui tiga metode. Pertama, melalui proses pembauran. Metode ini dilakukan dengn cara mereka masuk dan membaur ditengah-tengah masyarakat, setelah diterima masyarakat lantas mereka mulai menampakkan diri seperti dalam bentuk tindakan yang mengatas nemakan agama. Kedua, kaderisasi. Metode ini dilakukan dengan cara mendidik satu atau dua orang anggota kemudian hasil didikan diminta mengembangkan dan memengaruhi orang lain dengan cara memberikan doktrin seperti jalan jihad. Ketiga, melalui penggunaan media sosial. Metode ini merupakan cara yang paling ampuh dan banyak digunakan dalam meyebarkan paham radikalisme melalui diseminasi media sosial. Gerakan radikalisme tidak bisa dibiarkan dalam perkembangannya dan perlu adanya upaya penanggulangan yaitu melalui deradikaslisasi. Pada keutamaan tujuan dan fungsinya, deradikalisasi dimaksudkan untuk mencegah terjadinya eskalasi lanjutan dari sebuah tindakan kekerasan (Dechesne, 2011).

Deradikalisasi merupakan kemampuan dan strategi dalam upaya mengatasi segala bentuk ancaman dan gangguan seperti garis keras atau kekerasan terhadap identitas, integritas, eksistensi 
bangsa dan negara baik itu dalam aspek ideologi, politik, ekonomi, sosial budaya, dan keamanan. Deradikalisasi adalah upaya menetralisasi paham radikal bagi mereka yang terlibat aksi terorisme dan para simpatisanya, hingga meninggalkan aksi kekerasan (Hasani \& Naipospos, 2010). Deradikalisasi adalah proses suatu upaya untuk menghilangkan radikalisme (Prasetya \& Aprina, 2017). Deradikalisasi sebagai strategi pencegahan menjadi alternatif dari strategi kontra terorisme yang cenderung menggunakan kekerasan (Khamdan, 2015). Dalam upaya penanggulangan paham radikalisme (deradikalisasi), strategi yang dapat dilakukan adalah melalui penggunaan media sosial sebagai diseminasi informasi, media sosial merupakan alat komunikasi melalui internet yang mudah dan banyak digunakan di kalangan masyarakat.

Media Sosial adalah media online (daring) yang dimanfaatkan sebagai sarana pergaulan sosial secara online di internet. Di media sosial, para penggunanya dapat saling berkomunikasi, berinteraksi, berbagi, networking, dan berbagai kegiatan lainnya. Adapun jenis media sosial yang ada saat ini adalah youtube, facebook, twitter, instagram, whatsapp dan media sosial lainnya (Sari et al., 2020). Senada menurut (Jalonen, 2013), mengyatakan media sosial sebagai alat komunikasi memiliki fungsi (1) media komunikasi; (2) Media kolaborasi); (3) Media penghubung; (4) Media pelengkap; (5) Media penggabung. Media sosial sebagai ruang online yang populer berpotensi untuk membuat gerakan sosial mencapai publik yang lebih luas, sehingga fungsi ini penting terutama bagi kelompok aktivis yang tidak dikenal oleh masyarakat, apalagi jika agenda yang diusung oleh kelompok tersebut tidak mendapatkan perhatian dari media arus utama (Cammaerts \& Carpenteir, 2015).

Media sosial adalah media digital atau aplikasi berbasis internet yang disajikan secara online berupa jejaring sosial, wiki, blog, dunia virtual dan lain-lainnya yang mana didalamnya berisikan konten informasi yang memungkinkan diakses dan digunakan pengguna sebagai sarana komunikasi, interaksi dan berbagi informasi melalui ikatan atau komunitas sosial secara virtual (Utomo \& Prayogi, 2021). Penggunan Media sosial secara tidak langsung memungkinkan lahirnya bentuk baru dari organisasi sosial dan interaksi sosial berbasis jaringan informasi elektronik. Walaupun teknologi informasi tidak secara langsung menyebabkan perubahan sosial, namun teknologi ini merupakan bagian yang tidak terpisahkan dari banyaknya pergerakan dalam perubahan social (Anwar \& Rusmana, 2017). Effektifitas penggunaan media sosial sebagai diseminasi informasi pada dasarnya memberikan pengaruh besar pada pengetahuan dan pemahaman masyarakat. Pada kaitan ini, masyarakat harus cermat dan teliti dalam menganalisis setiap informasi yang ia terima agar tidak terpengaruh pada informasi yang mengandung unsurunsur paham radikalisme. Masyarakat harus hati-hati dan mampu menyikapi dengan bijak agar tidak mudah terpengaruh dari informasi-informasi yang disebarkan melalui media sosial.

Berdasarkan paparan pada studi pendahuluan yang telah diuraikan di atas, tujuan kegiatan Pengabdian kepada Masyarakat $(\mathrm{PkM})$ ini adalah untuk memotret perilaku sosial masyarakat Bengkulu terhadap penggunaan media sosial sebagai diseminasi informasi, bimbingan pribadisosial dan deradikasisasi. Fokus kegiatan pengabdian ini meninjau tentang (1) Potret perilaku sosial masyarakat terhadap penggunaan media sosial sebagai diseminasi informasi; (2) Potret perilaku sosial masyarakat terhadap penggunaan media sosial sebagai bimbingan pribadi-sosial (pembentukan sikap dan perilaku) dan deradikalisasi.

\section{METODE}

Kegiatan Pengabdian kepada Masyarakat (PkM) ini dilaksanakan untuk memotret perilaku sosial masyarakat Bengkulu terhadap penggunaan media sosial sebagai diseminasi informasi, bimbingan pribadi-sosial dan deradikasisasi. Pelaksanaan kegiatan pengabdian ini dilaksanakan melalui lima tahapan (1) Tahap perencanaan, meliputi penyusunan konsep pengabdian, penyusunan instrument, penyusuan aplikasi survei, pengujian aplikasi survei dan uji validitas dan reliabilitas; (2) Tahap pelaksanaan, meliputi proses pengempulan data; (3) Tahap penjajagan, meliputi cleaning data, validasi data dan uji petik, tabulasi data; (4) Tahap pelaporan, meliputi 
finalisasi dan penyususnan laporan; (5) Tahap evalusasi, meliputi audit kegiatan. Kegiatan pengabdian ini menggunakan pendekatan kuantitatif yang mana banyak menggunakan angkaangka, mulai dari mengumpulkan data, penafsiran terhadap data serta penampilan dari hasilnya (Arikunto, 2010). Sedangkan Metode yang digunakan menggunakan metode survei, menurut (Kriyantono, 2008) metode survei adalah metode riset dengan menggunakan kuisioner sebagai instrumen pengumpulan datanya, tujuannya untuk memperoleh informasi tentang sejumlah responden yang dianggap mewakili populasi tertentu.

Kegiatan Pengabdian kepada Masyarakat (PkM) ini dilaksanakan pada tahun 2020, lokasi pelaksanaan kegiatan pengabdian ini terbagi menjadi empat tempat, yaitu (1) Kota Bengkulu; (2) Kab. Seluma; (3) Kab. Kepahiang; (4) Kab. Mukomuko. Jumlah sampel keseluruhan adalah 400 responden, responden dipilih dan dibagi menjadi tiga klasifikasi, yaitu (1) Generasi Gen Z (usia 14-19 tahun); (2) Generasi Millenial (usia 20-39 tahun); (3) Generasi Generasi Gen X (Usia 4055 tahun). Pengambilan sampel menggunakan multistage random sampling.

Teknik pengumpulan data menggunakan skema mobile survey, data diperoleh melalui proses deep interview dan kuisioner via mobile. Proses pengambilan data dengan skema mobile survey diuraikan pada gambar berikut:

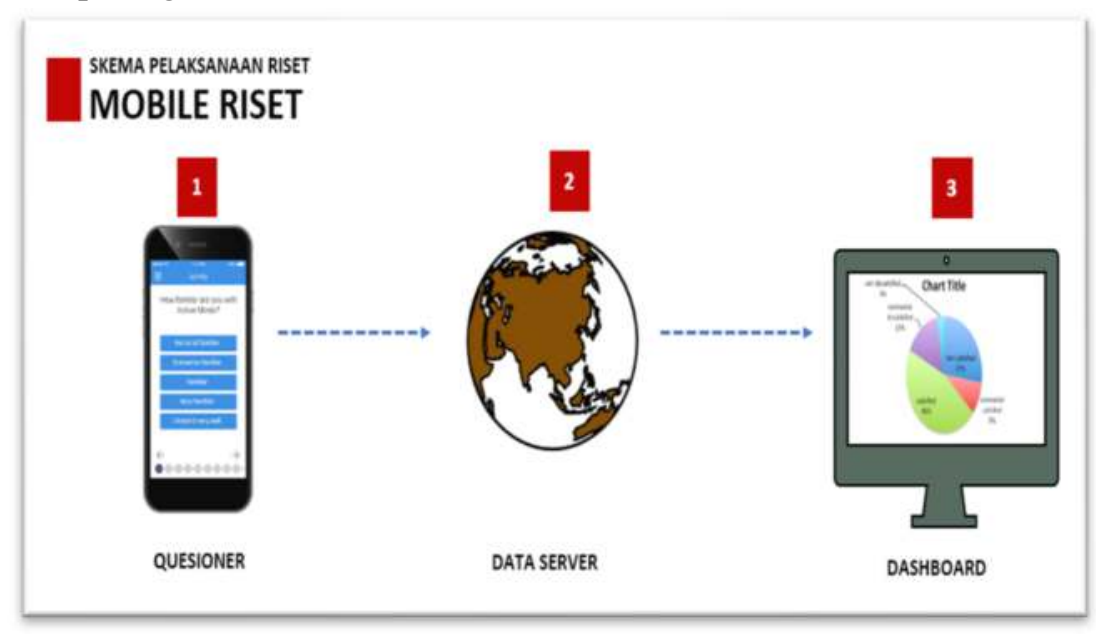

Gambar 1. Skema Mobile Survey

Pengumpulan data menggunakan skema mobile survey merupakan alat pengumpul data berbasis media digital, data yang diperoleh dari responden kemudian langsung di input pada aplikasi survei. Proses pengambilan data dengan skema mobile survey, maka progress survey akan menjadi lebih cepat, terkontrol dan realtime. Analisis data menggunakan aplikasi survey (alvaraanalytic).

\section{HASIL DAN PEMBAHASAN}

Hasil kegiatan pengabdian ini dikategorikan menjadi dua fokus pembahasan, yaitu (1) Potret perilaku sosial masyarakat terhadap penggunaan media sosial sebagai diseminasi informasi ; (2) Potret perilaku sosial masyarakat terhadap penggunaan media sosial sebagai bimbingan pribadisosial (pembentukan perilaku) dan deradikalisasi. Hasil Temuan diuraikan berikut:

Pertama, potret perilaku sosial masyarakat terhadap penggunaan media sosial sebagai diseminasi informasi hasil temuan menunjukkan (1) Durasi akses internet mesyarakat dengan menggunakan akses internet sebesar 69\%, dan tidak menggunakan akses internet sebesar $31 \%$. Hasil temuan menunjukan mayoritas masyarakat menggunakan akses internet; (2) Akun media sosial yang digunakan masyarakat antara lain Facebook sebesar 95,9\%; Instagram sebesar 25,2\%; Tiktok sebesar 5,2\%; dan Twiter sebesar 2,6\%. Hasil temuan menunjukan Facebook menjadi akun 
sosial media yang paling banyak digunakan masyarakat; (3) Akun messaging yang digunakan masyarakat antara lain Whatsapp sebesar 87,8\%; Facebook Messenger sebesar 37,4\%; Telegram sebesar $1,9 \%$; dan Line sebesar 1,1\%. Hasil temuan menunjukan Whatsapp menjadi akun sosial media yang paling banyak digunkan masyarakat; (4) Media akun yang digunakan masyarakat anatara lain Youtube sebesar 67,9\%; Sosial Media (facebook, Twiter dll) sebesar 48,2\%; dan Website sebesar 23,2\%. Hasil temuan menunjukan Youtube menjadi media akun yang paling banyak digunakan masyarakat.

Kedua, potret indeks potensi radikalisme pada masyarakat Bengkulu hasil temuan menunjukkan (1) Indeks potensi radikalisme provinsi Bengkulu sebesar 14,1\%. Hasil temuan menunjukkan nilai indeks potensi radikalisme provinsi Bengkulu berada kategori rendah; (2) Dimensi potensi radikalisme provinsi Bengkulu pada dimensi pemahaman sebesar 9,7\%; sikap sebesar 27,2\%; dan tindakan sebesar 5,6\%. Hasil temuan menunjukkan dimensi sikap merupakan dimensi dengan indeks tertinggi; (3) Indeks potensi radikalisme berdasarkan generasi Gen Z sebesar 14,5\%; Milenial sebesar 14,4\% dan Gen X sebesar 13,3\%. Hasil temuan menunjukkan indeks potensi radikalisme generasi Gen Z dan Milenial cenderung lebih tinggi; (4) Indeks Potensi Radikalisme Berdasarkan Akses Internet sebesar 13,8\% dan indeks potensi radikalisme yang tidak berdasarkan akses internet sebesar 14,9\%. Hasil temuan menunjukkan indeks potensi radikalisme yang tidak berdasarkan akses internet cenderung lebih tinggi dibandingkan yang tidak berdasarkan akses internet; (5) Indeks potensi radikalisme berbasis literasi digital pada kategori rendah sebesar 14,3\%; dan pada kategori sedang sebesar 9,4\%; dan pada kategori tinggi sebesar $20,4 \%$. Hasil temuan menunjukkan Indeks potensi radikalisme cenderung lebih tinggi pada mereka yang terliterasi.

1. Potret Perilaku Sosial Masyarakat terhadap penggunaan media sosial sebagai Diseminasi Informasi

Mayoritas masyarakat melek digital, mereka aktif mengunakan media sosial untuk kebutuhan sehari-hari seperti Facebook, Youtube, Twitter dan media sosial lainnya adalah jenis media yang paling banyak digunakan. Disamping itu mereka menggunakan media sosial sebagai alat komunikasi, berinteraksi dan berbagi informasi. Penggunaan media sosial sebagai diseminasi informasi memiliki andil besar bagi masyarakat terhadap pembentukan sikap dan perilaku, hal ini dapat dilihat masyarakat dapat dengan bijak menggunakan media sosial untuk hal-hal positif (kebutuhan).

Hasil temuan mengungkap media sosial memiliki edukasi terhadap pembentukan perilaku sosial masyarakat. Bimbingan pribadi-sosial disini adalah proses mengarahkan masyarakat untuk berperilaku bijak didalam menggunakan dan menyebarkan media sosial. Terdapat lima temuan efektivitas penggunaan media sosial sebagai bimbingan pribadi-sosial terhadap pembentukan perilaku sosial masyarakat. Pertama, masyarakat dapat dengan bijak dan tidak mudah terpapar kerentanan sosial. Perilaku sosial masyarakat menunjukkan mereka tidak mudah terpengaruh ketika menerima konten informasi yang berkaitan dengan kerentanan sosial (isu-isu radikal, HOAX, Sara, ujaran kebencian dan sebagainya) mereka cenderung mengabaikan dan tidak mempedulikan.

Kedua, perilaku sosial masyarakat terhadap penggunaan dan diseminasi media sosial menunjukkan (1) Attention, masyarakat memperhatikan dan membaca ketika menerima konten informasi; (2) Interest, jika konten informasi memberikan kebermanfatan masyarakat membacanya secara keseluruhan; (3) Search, masyarakat mencari kebenaran konten informasi yang diterima dengan cara mencari informasi pembanding; (4) Action, masyarakat percaya dan yakin atas konten informasi yang diterima kemudian dijadikan proses pembelajaran diri; (5) Share, masyarakat menyebar/membagikan konten informasi tersebut kepada orang lain sebagai informasi.

Ketiga, media sosial sebagai sarana membangun diri (edukasi) bagi masyarakat, hal ini dapat dilihat konten informasi yang sering diakses dan dicari dan disebarkan masyarakat yaitu 
Indonesian Journal of Community Services

Volume 3, No. 2, November 2021

http://jurnal.unissula.ac.id/index.php/ijocs

DOI: http://dx.doi.org/10.30659/ijocs.3.2.193-202

tentang (1) Pola hubungan antar manusia; (2) Tatacara peribadatan (sholat); (3) Tema yang lagi hit/kekinian; (4) Berita nasional; (5) Hukum dalam agama; (6) Ekononomi. Konten informasi tersebut menjadi pilihan favorit dan banyak dicari oleh masyarakat dalam penggunaan media sosial.

Keempat, media sosial sebagai sarana membimbing diri baik secara individu maupun sosial, hal ini dapat dilihat konten informasi yang sering diakses dan dicari dan disebarkan masyarakat yaitu tentang (1) Tata cara peribadatan; (2) Sejarah keagamaan/ utusan tuhan sebesar; (3) Nasib saudara seiman ditempat lain; (4) Ketidakadilan negara terhadap agama tertentu sebesar; (5) Penistaan agama; (6) Ujaran kebencian sebesar; (7) Aliran sesat. Konten informasi tersebut paling banyak dicari masyarakat hal ini dikarenakan banyak memberikan kebermanfaat bagi diri sendiri dan orang lain secara umumnya.

Kelima, perilaku sosial masyarakat terhadap penggunaan media sosial adalah dengan tujuan untuk saling berbagi informasi (membimbing diri dan orang lain) dan memberikan informasi kepada pengguna lain yang membutuhkan. Masyarakat memandang diseminasi media sosial adalah cara paling praktis dan efektif dalam menyebarkan informasi dimana memiliki keuntungan yaitu mudah disebarkan ke pengguna lain. Disamping itu, masyarakat menggunakan media sosial yaitu memudahkan mereka dalam berkumunikasi, berinteraksi dan berbagi dengan masyarakat lainnya, bagi masyarakat media sosial memiliki keunggulan dibandingkan dengan media konvensional. Menurut masyarakat, keunggulan menggunakan media sosial antara lain (1) Cepat, ringkas, simpel dan mudah; (2) Menciptakan hubungan lebih intens (terbuka/umum dan tertutup/pribadi); (3) Jangkauan luas dan global.

Keberadaan media sosial juga telah melahirkan bisnis baru, masyarakat menggunakan media sosial sebagai ajang bisnis dan dijadikan sebagai sumber penghasilan dan membantu masyarakat dalam menjalankan usahanya untuk meningkatan pendapatan dan keuntungan ekonomi. Keuntungan yang dimaksud menurut (Rushendi \& Suryantini, 2019) yaitu dengan menggunakan media sosial sebagai sarana diseminasi, akan diperoleh keuntungan ganda, yaitu biaya sangat murah (bahkan tanpa biaya), dan efek penyebaran sangat cepat dan luas, juga langsung dapat diketahui jumlah orang yang telah melihat dan respons mereka. Dari maksud tersebut, memaknai bahwa motif tujuan masyarakat menggunakan diseminasi media sosial yaitu penyebaran informasi melalui media sosial berlangsung secara cepat dan orang lain dapat mengakses informasi yang disebarkannya. Penggunaan media sosial melalui perilaku online masyarakat memiliki dampak yang besar terhadap perkembangan pengetahuan dan pendapatan ekonomi masyarakat.

Potret perilaku sosial masyarakat terhadap penggunaan dan diseminasi media sosial menunjukkan bahwa mereka aktif menggunakan media sosial sebagai sarana berbagi informasi kepada masyarakat lainnya, masyarakat memanfaatkan fitur-fitur yang ada di media untuk menyebarkan informasi seperti (1) Postingan (status); (2) menyukai (like); (3) membagikan (share); (4) komentar (comment); (5) cerita (story). Sebagai contoh, mereka memanfaatkan fiturfitur media sosial untuk menyebarkan konten informasi tentang (1) Kerukunan antar kelompok; (2) Saling menghormati dan menghargai; (3) Tolong menolong dalam hal kebaikan; (4) Ajaran nilai-nilai agama; (5) Moderat; (6) Bersikap adil; (7) Menjaga solidaritas dan persaudaraan dalam kelompok. Mereka menyebarkan konten informasi tersebut tujuan untuk edukasi, yaitu sebagai pembelajaran bagi diri dan orang lain dalam kehidupan bermasyarakat.

2. Potret Perilaku Sosial Masyarakat Terhadap Penggunaan Media Sosial Sebagai Bimbingan Pribadi-Sosial (Pembentukan Sikap dan Perilaku) dan Deradikalisasi

Penggunaan dan diseminasi media sosial efektif dapat membimbing masyarakat terhadap pembentukan perilaku sosial dalam cegah tangkal paham radikalisme (deradikalisasi). Terdapat lima temuan yang dapat diungkap. Pertama, indeks potensi radikalisme di Provinsi Bengkulu pada tahun 2020 berada dalam kategori rendah dikarenakan masyarakat mampu dengan baik menggunakan media sosial sebagai pendidikan berbasis masyarakat (deradikalisasi). Tegasnya, 
media sosial digunakan masyarakat sebagai informasi, inovasi dan strategi dalam penanggulangan paham radikalisme (deradikalisasi). Hal ini dapat dilihat konten informasi yang diakses dan disebarkan masyarakat berisikan tentang (1) Strategi taktis dan cara-cara yang harus dilakukan masyarakat dalam mengahadapi dan menangkal berbagai terpaan dan kerentanan sosial (radikalisasi); (2) Pemahaman dan pengembangan nilai-nilai multikultural di masyarakat sebagai kekuatan dalam menghadapi serangan luar; (3) Strategi alternatif dan inovasi dalam menghadapi isu-isu global yang dapat mengancam dan memecah belah tatanan kehidupan masyarakat.

Kedua, masyarakat menggunakan media sosial sebagai strategi dalam penanggulangan paham radikalisme (deradikalisasi) dengan tujuan untuk (1) Meningkatkan pemahaman dan kesadaran masyarakat akan bahaya dan dampak dari radikalisasi; (2) Memperkuat sistem tatanan sosial masyarakat dan siap tanggap dalam melawan radikalisme; (3) Menjaga kerukunan dan keharmonisan masyarakat mengingat mereka terdiri dari berbagai kelompok (suku); (4) Menumbuhkan dan menguatkan proses demokratisasi dalam kehidupan masyarakat; (5) Menjaga keamanan masyarakat; (5) Mencegah dan menangkal paham dan gerakan radikal yang bertentangan dengan norma-norma masyarakat.

Ketiga, Isi materi konten informasi yang diakases dan disebarkan masayarakat dalam penanggulangan paham radikalisme (deradikalisasi) melalui media sosial meliputi (1) Menumbuhkan kesadaran masyarakat bahwa kesatuan dan persatuan adalah milik dan tanggung jawab bersama; (2) Perlunya mobilisasi masyarakat agar tergerak dan terstimulir untuk sigap dan cepat tanggap dalam menangkal radikalisme; (3) Melaksanakan tahapan kerja konkret meliputi kegiatan-kegiatan pelatihan/diklat pemberdayaan masyarakat; (4) Sosialisasi pentinnya memelihara kesatuan dan persatuan bangsa.

Keempat, bentuk-bentuk konten informasi yang diakases dan disebarkan masayarakat dalam penanggulangan paham radikalisme (deradikalisasi) melalui media sosial meliputi (1) Tujuan dan program-program kerja masyarakat yang berorientasi deradikalisasi; (2) Pengorganisasian (tugas pokok dan fungsi) masyarakat dalam cegah tangkal radikalisme; (3) Model-model tindakan dalam mengahadapi masuknya gerakan radikalisme; (4) Pengendalian dan peran masyarakat dalam mengontrol isu-isu radikalisme.

Kelima, sikap dan tanggapan masyarakat dalam mengakses dan menyebarkan konten informasi tentang pentingnya program deradikalisasi dalam cegah tangkal radikalisme antara lain (1) Meyakini radikalisme adalah gerakan yang ditentang dalam agama; (2) Meyakini bahwa radikalisme dapat memecah belah kesatuan bangsa dan negara; (3) Percaya bahwa radikalisme adalah gerakan yang mengandung terorisme; (4) Meyakini bahwa semua masyarakat memiliki hak dan tanggung jawab secara bersama-sama dalam mencegah radikalisme.

Hasil temuan sebagaimana diungkap di atas memaknai bahwa deradikalisasi merupakan gagasan dan upaya menghilangkan faham radikal. Terdapat banyak pendekatan yang dapat dilakukan sebagai daya tangkal paham terorisme, daya tangkal tersebut meliputi (1) kepercayaan hukum, (2) Kesejahteraan sosial, (3) Norma-norma masyarakat, (4) Keadilan sosial, (5) Kebebasan sosial, (6) Keagamaan, dan (7) Kearifan lokal. Menurut (Musyafak, 2017) menyatakan deradikalisasi merupakan proses panjang melalui pendekatan multidisipliner seperti hukum, sosial, psikologi, komunikasi, ekonomi, agama dan budaya yang membutuhkan keseriusan, ketokohan dan keahlian khusus untuk mendapatkan hasil maksimal. Senada menurut (Ashour, 2008) mengemukakan deradikalisasi merupakan sebuah proses yang mendorong individu atau kelompok untuk mengubah sikapnya tentang kekerasan, khususnya terhadap warga sipil. Pada esensi utamanya, deradikalisasi merupakan sebuah alat strategis untuk melawan radikalisme-terorisme.

Temuan lain mengungkap bahwa deradikalisasi yang dilakukan masyarakat sesungguhnya adalah untuk meluruskan dan mengembalikan pemahaman Islam sebagai agama yang damai, menghilangkan pemahaman radikal menyangkut konsep jihad yang diusung para paham radikal. Konsep tersebut jelas-jelas keliru dan salah dimana Islam sesungguhnya adalah agama yang cintai 
Indonesian Journal of Community Services

Volume 3, No. 2, November 2021

http://jurnal.unissula.ac.id/index.php/ijocs

DOI: http://dx.doi.org/10.30659/ijocs.3.2.193-202

damai. Sejauh ini, organisasi keagamaan khususnya Islam telah melakukan langkah-langkah deradikalisasi seperti (1) Meluruskan kembali ajaran-ajaran Islam yang disesatkan; (2) Memberikan penegasan bahwa seorang radikalis justru dilaknat oleh Allah SWT; (3) Memberikan landasan agama bahwa Islam adalah agama perdamaian, universal dan menentang segala bentuk radikalisme; (4) Memberikan landasan agama sebagai penyeimbang hidup antara dunia dan akhirat (Qodir, 2012). Dilihat dari faktor penyebabnya, Lazuardi mengemukakan radikalisme sendiri dipengaruhi beberapa hal, antara lain; pemahaman Islam yang cenderung legalistik dan ekslusif, penghargaan terhadap kelompok minoritas yang rendah, perasaaan terasing dari kehidupan kolektif (merasa umat Islam dipojokan), dan hadirnya organisasi-organisasi gerakan radikal (Bakti, 2015). Padahal, misi ajaran Islam yang sebenarnya sangat mulia dan luhur itu seringkali justru mengalami distorsi akibat pamahaman yang keliru terhadap beberapa aspek ajaran Islam yang berpotensi menimbulkan radikalisme (Munip, 2012).

Deradikalisasi berbasis masyarakat tidak hanya memfokuskan pada subjek masyarakat (orang dewasa) itu sendiri tetapi juga pada anak (remaja), mengingat saat ini anak banyak dijadikan sebagai sasaran utama. Program deradikalisasi pada anak antara lain (1) Pemberian bekal kepada anak didik untuk mampu berfikir secara kritis dan analitis sehingga tidak menerima informasi begitu saja sebagai kebenaran absolute tanpa disaring terlebih dahulu; (2) Menanamkan pemahaman multikulturalisme dan demokrasi; (3) Menyusun pengajaran yang dialogis; (4) Melatih anak didik untuk berargumen dan menyanggah suatu argumen; (5) Memberikan soal khusus kepada anak didik untuk dianalisis (Agus, 2016)). Melalui program deradikalisasi anak, adalah dimaksudkan untuk memberi bekal dan konsep pemikiran anak agar nantinya mereka tidak terjerumus masuk kedalam kelompok radikalisme.

Program deradikalisasi yang dilakukan masyarakat merupakan upaya mencegah (preventif) dan upaya mengatasi (kuratif) masuknya gerakan radikal yang dapat membahayakan masyarakat seperti ancaman, kekerasan, peperangan dan teror melalui jejaring sosial (media sosial). Sejauh ini, deradikalisasi telah dilakukan oleh berbagai pihak seperti pemerintah melalui lembaga Badan Nasional Penanggulanagan Terorisme (BNPT) dan Forum Koordinasi Pencegahan Terorisme (FKPT), lembaga pendidikan, kepolisian, masyarakat dan ormas yang mana telah berupaya melakukan pencegahan dan penanggulan agar gerakan radikalisme tidak menyebar luas di tiaptiap daerah.

\section{KESIMPULAN}

Potret perilaku sosial masyarakat Bengkulu terhadap penggunaan media sosial sebagai diseminasi informasi, bimbingan pribadi-sosial dan deradikasisasi hasil temuan menunjukkan bahwa (1) Mayoritas masyarakat melek digital dan aktif mengunakan media sosial untuk kebutuhan seharihari; (2) Facebook, Youtube,Twitter, Instagram, Tiktok dan sebagainya adalah media sosial yang paling banyak digunakan; (3) Perilaku sosial masyarakat terhadap penggunaan dan diseminasi media sosial menunjukkan meliputi attention, interest, search action, share; (4) Indeks potensi radikalisme di Provinsi Bengkulu pada tahun 2020 berada dalam kategori rendah; (5) Dimensi potensi radikalisme provinsi Bengkulu pada dimensi pemahaman sikap berada dalam kategori rendah; (6) Indeks potensi radikalisme berdasarkan akses internet lebih kecil dibandingkan dengan yang tidak berdasarkan akses internet.

Saran dan rekomendasi yang ditawarkan antara lain (1) manfaat praktis: hasil kegiatan pengabdian ini dapat dijadikan sebagai referensi terkait tinjauan tentang peran penggunaan dan diseminasi media sosial sebagai informasi, inovasi dan strategi penanggulangan paham radikalisme (deradikalisasi); (2) Peneliti selanjutnya dapat mempertimbangkan keterbatasanketerbatasan dalam kegiatan pengabdian ini; (3) Dapat dijadikan sebagai kebaruan kegiatan pengabdian (Novelty) penggunaan media sosial sebagai informasi, inovasi dan strategi penanggulangan paham radikalisme (deradikalisasi); (4) Media sosial dapat dijadikan sebagai piranti (alternatif metode) dan strategi penanggulangan paham radikalisme (deradikalisasi); (5) 
hasil kegiatan pengabdian ini dapat dijadikan sebagai acuan dan referensi/rujukan dalam penanggulangan paham radikalisme (deradikalisasi) melalui media sosial.

\section{DAFTAR PUSTAKA}

Agus, S. (2016). Deradikalisasi Nusantara, Perang Semesta Berbasis Kearifan Lokal melawan Radikalisasi dan Terorisme. Daulat Press.

Anwar, R., \& Rusmana, A. (2017). Komunikasi Digital Berbentuk Media Sosial Dalam Meningkatkan Kompetensi Bagi Kepala, Pustakawan, Dan Tenaga Pengelola Perpustakaan (Studi Kasus pada Sekolah/Madrasah di Desa Kayu Ambon, Kecamatan Lembang Kabupaten Bandung Barat). Dharmakarya: Jurnal Aplikasi Ipteks Untuk Masyarakat, 6(3), 204-208.

Arikunto, S. (2010). Prosedur Penelitian: Suatu Pendekatan Praktik. Rineka Cipta.

Ashour, O. (2008). Islamist De-Radicalization in Algeria: Successes and Failures. Middle East Institute Policy Brief.

Bakti, A. (2015). Terorisme dan Tantangan Radikalisme Baru Dalam Sistem Kepemimpinan Nasional. Strategic Outlook: Jurnal Politik Dan Keamanan Nasional.

Cammaerts, B., \& Carpenteir, N. (2015). Reclaiming the Media: Communication Rights and Democratic Media Roles. Intellect Inc.

Dechesne, M. (2011). Deradicalization: not soft, but strategic. Crime Law Social Change, 5, $287-$ 292.

Golose, P. (2009). Deradikalisasi Terorisme: Humanis, Soul Approach, dan Menyenuh Akar Rumput. Yayasan Pengembangan Kajian Ilmu Kepolisian.

Hasani, I., \& Naipospos, B. (2010). Radikalisme Agama di Jabodetabek \& Jawa Barat:Implikasinya terhadap Jaminan Kebebasan Beragama/Berkeyakinan. Pustaka Masyarakat Setara.

Jalonen, M. (2013). Social Media and Emotions in Organizational Knowledge Creation. ACSIS, 1371-1379.

Khamdan, M. (2015). Rethinking Deradikalisasi: Konstruksi Bina Damai Penanganan Terorisme. ADDIN Press.

Kriyantono, R. (2008). Teknik Praktis Riset Komunikasi. Prenadamedia Group.

Munip, A. (2012). Menangkal radikalisme agama di sekolah. Jurnal Pendidikan Islam, 1(2), 159181.

Musyafak, N. (2017). Deradikalisasi NKRI: Pesan Damai dari Jawa Tengah. CV. Raf Sarana Perkasa.

Prasetya, B., \& Aprina, C. (2017). Peran Pondok Pesantren dalam Deradikalisasi Paham dan Gerakan Islam Radikal (Studi Pondok Pesantren Riyadlatul Ulum Batanghari Lampung Timur). Artikel Dalam Fikr, 2(2), 289.

Qodir, Z. (2012). Deradikalisasi Islam Dalam Perspektif Pendidikan Agama. Jurnal Pendidikan Islam, 1(2), 98-100.

Rushendi, \& Suryantini, H. (2019). Pemanfaatan Media Sosial Dalam Diseminasi Inovasi Tanaman Rempah. Jurnal Perpustakaan Pertanian, 28(2), 50-56. 


\section{Indonesian Journal of Community Services}

Volume 3, No. 2, November 2021

http://jurnal.unissula.ac.id/index.php/ijocs

DOI: http://dx.doi.org/10.30659/ijocs.3.2.193-202

Salenda, K. (2011). Terorisme dan Jihad. al-Zikra.

Sari, S., Hutabarat, \& Sylvana, M. (2020). Pendampingan Penggunaan Media Sosial Yang Cerdas Dan Bijak Berdasarkan Undang-Undang Informasi Dan Transaksi Elektronik. Diseminasi: Jurnal Pengabdian Kepada Masyarakat, 2(1).

Utomo, P., \& Prayogi, F. (2021). Literasi Digital: Perilaku dan Interaksi Sosial Masyarakat Bengkulu Terhadap Penanaman Nilai-nilai Kebhinekaan Melalui Diseminasi Media Sosial. Indonesian Journal of Social Science Education (IJSSE), 3(3), 65-76. https://doi.org/http://dx.doi.org/10.29300/ijsse.v3i1.4306 